\title{
Management Of Banking System Liquidity In The Czech Republic
}

Karel Bruna, University of Economics, Prague, Czech Republic

\begin{abstract}
Implementation of monetary policy assumes that monetary policy instruments stabilize O/N interest rates to the proximity of main policy rate to achieve monetary targets. The function of stabilizing mechanism is based on simple rule that the volume of liquidity in the banking system is held in line with the demand of banks for reserves. In this paper main factors of banking system liquidity are analyzed in the context of bank's imperfect intertemporal substitution of reserves and with respect to predictibility of O/N interest rates volatility. Analysis of O/N PRIBOR and CZEONIA reference interest rates prove Czech National Bank's ability to stabilise O/N interest rates disregard overall excess liquidity in the banking system. It also identified structural changes acting in the money market like reduced instability of demand for reserve and decreased volatility of O/N interest rates due to intdroduction of credit facility or increased volatility of the spread between $\mathrm{O} / \mathrm{N}$ interest rates and repo rate due to reduction of frequency of repo tenders. Rapid increase in the volatility of differences between OMO target and bank's supply of excess reserves is also resulting in the weakening of a direct relationship between O/N PRIBOR dynamics and repo tenders.
\end{abstract}

Keywords: monetary policy implementation; liquidity management; interest rates

\section{INTRODUCTION}

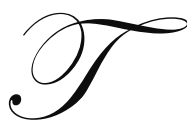

he present financial crisis confirms that central banks play a crucial role in the banking system liquidity management. The majority of developed countries operate under conditions when the central bank supplies liquidity to commercial banks. Management of banking system liquidity is performed by the same tools that are used for the attainment of stable and low inflation rate. Therefore the practical liquidity management has to be consistent with the level of the main policy rate that is announced by central banks with regard to defined inflation target and expected dynamics of inflationary factors. The method of central bank's management of the banking system liquidity has immediate impacts on the dynamics of $\mathrm{O} / \mathrm{N}$ interest rates in the interbank market. The main policy rate functions as a gravitational core of ultra-short interest rates and the volatility of $\mathrm{O} / \mathrm{N}$ interest rates reflects a short-time difference between the supply of liquidity by central bank and demand of other banks for liquidity.

The Czech National Bank (CNB) is brought to quite a unique position from the aspect of the banking system liquidity management and in the context of monetary policy implementation. Contrary to standard practice, the banking system in the Czech Republic works with liquidity surplus and so CNB has to withdraw excess liquidity from the banking system regularly. Such a situation is an immediate consequence of CNB interventions to prevent the Czech crown appreciation against foreign currencies. CNB has to cope with this situation under conditions when as the first bank among transition economies it adopted explicit inflation targeting by means of standard instruments of monetary policy known from the practice of advanced central banks.

The objective of this paper is to define theoretically the basic problems of the banking system liquidity management in the context of monetary policy implementation and with regard to the dynamics of $\mathrm{O} / \mathrm{N}$ interest rates. The goal of an empirical analysis is the practical application of these general principles on an example of implementation of the CNB strategy of inflation targeting, liquidity management in the situation of liquidity surplus in the Czech banking system and dynamics of reference interest rates in the Czech interbank market. 


\section{MONETARY POLICY IMPLEMENTATION AND BANKING SYSTEM LIQUIDITY MANAGEMENT}

One of the necessary conditions for the attainment of envisaged effects of monetary policy is central bank's ability to stabilize the price of the banking system liquidity around the announced main policy rate. In the implementation of monetary policy it is basically necessary to set such conditions for the use of monetary-policy instruments that will solve the problem of the fundamental deficit or surplus of the banking system liquidity and at the same time that will allow to react flexibly to daily volatility of the demand of banks for liquidity and to trend changes in the need of liquid resources under such price conditions that are consistent with the announced level of the main policy rate.

Open market operations are a key instrument for the realization of central banks' monetary plans and for the banking system liquidity management. The attainment of the targeted level of main policy rate and stabilization of $\mathrm{O} / \mathrm{N}$ interest rates assume the development of a system of periodic tenders for the supply/withdrawal of liquidity to/from the banking system. From the technical aspect daily volatility of the demand for central bank's reserves is usually solved by the regular supply/withdrawal of liquidity through reverse/standard repo operations. The frequency and maturity of such tenders reflect the ratio between the volatility of factors influencing the aggregated volume of reserves of banks with central bank and the average level of these reserves, i.e. banking systems with relatively high volatility of liquidity tend to invite for tenders on a daily basis while the liquidity is often supplied/withdrawn with overnight maturity. Trend factors behind the permanently growing average demand of banks for liquidity are often covered by the outright repurchase of securities. The frequency of these operations is naturally lower, and from the monetary-policy aspect they are not applied in order to influence the dynamics of market interest rates.

In connection with the actual shape of monetary policy implementation the institute of minimum reserves is undergoing a significant change in the purpose of use (see Bindseil, 2004; Bindseil, U., Camba-Mendez, G., Hirsch, A, Weller, B., 2004). Minimum reserves are not currently used as a tool of enforcing monetary restriction/expansion but they are understood as a crucial factor stabilizing the demand of the banking system for liquidity/the supply of surplus reserves. It is important from the aspect of volatility of $\mathrm{O} / \mathrm{N}$ interest rates that the balance of banks on the account of reserves with central bank is averaged for the so called maintenance period for the purposes of replenishing minimum reserves. It means that in the case of the banking system liquidity shocks banks can cover variations in the replenishment of minimum reserves by an adequate change in the demand for liquidity on subsequent trade days, and thanks to it the problem may efficiently be solved only by a limited impact on the instability of $\mathrm{O} / \mathrm{N}$ interest rates.

The deposit and/or lending facility of central bank is a complementary means that enables the banking system to handle mainly the deficit/surplus of liquidity of greater volume at the end of the day, which determines an effective limit for the volatility of $\mathrm{O} / \mathrm{N}$ interest rates. The implementation of monetary policy in this context assumes that central bank's approach to the banking system liquidity management will eliminate the need of using facilities due to expected liquidity shocks. Ultimately, there should exist ex ante the same probability of using deposit and lending facility under unexpected changes in the banking system liquidity.

The fundamental deficit of the banking system liquidity is a consequence of the specific position of central bank in the domestic interbank payment system. The payment system operates through banks that open accounts for the clearing of interbank payments with central bank, which may automatically imply the need of liquidity acquisition from central bank. As stated by Woodford (2001) or Whitesell (2003), if the central bank does not apply the institute of minimum reserves, it is imaginable that the targeting of main policy rate will take place under the onaverage zero aggregate demand of banks for the liquidity of central bank.

On the other hand, the on-average zero demand for the liquidity of central bank assumes that the transactions between banks and central bank by means of which banks acquire liquidity represent perfect substitutes of dealings with existing liquidity in the interbank market. Whitesell (2006) stated that liquidity in both markets was not perfectly substitutable due to a different credit risk of operations between banks and central bank and among banks in the interbank market, different securing of transactions by help of the collateral/pledge of securities or penalization of interest rate for negative balances of banks on the account of reserves with central bank. Ultimately, 
each of these factors implies that in liquidity management banks cannot rely on the interbank market only. Even in the system without official demands on the reserves the banking system has a tendency of demanding the on-average non-zero volume of liquidity that will allow them to increase flexibility in operations with liquidity and to avoid complicated price and volume conditions in extreme situations.

By its nature the positive demand of banks for central bank's liquidity is similar to the need of maintaining a certain precautionary reserve whereas its size is assumed to be related with the volume of deposits in the banking system. The use of balances on the reserve account for the interbank system of payment is directly associated with the volume of current deposits, the handling of which requires certain flexibility from banks in the management of their liquid positions. On the other hand, the lending activity of banks assumes that a bank credit can be granted to nonbank clients if the bank has access to liquidity on the reserve account. The coherence between lending activity of banks, volume of bank deposits and consequently demand for central bank's liquidity lies in the process within which the major portion of bank deposits originates on the basis of multiplication through the lending activity of banks.

Table 1: Central bank's balance sheet in the context of autonomous factors and monetary policy instruments Assets Liabilities

\begin{tabular}{|c|c|}
\hline \multicolumn{2}{|c|}{ Autonomous factors } \\
\hline & Currency in circulation \\
\hline & Government deposits \\
\hline & Excess reserves \\
\hline \multicolumn{2}{|c|}{ Items connected with monetary policy instruments } \\
\hline $\begin{array}{l}\text { Foreign exchange reserves } \\
\text { (foreign exchange interventions) }\end{array}$ & Minimum reserves \\
\hline Securities (open market operations supplying liquidity) & $\begin{array}{l}\text { Bank's deposits/securities issued by central bank (open market } \\
\text { operations withdrawing liquidity) }\end{array}$ \\
\hline Securities (lending facility) & Bank’s deposits (deposit facility) \\
\hline \multicolumn{2}{|c|}{ Other items } \\
\hline Gold & Capital \\
\hline Tangible and intangible assets & Retained profit/loss outstanding \\
\hline Other assets & Other liabilities \\
\hline
\end{tabular}

In line with the present conception of monetary policy central banks continue to increase the degree of the banking system dependence on liquidity supplied by central bank by defining a certain minimum level of reserves that exceeds the above discussed "emergency" demand of banks for central bank's liquidity. The effects of such policy are double (see Table 1). On a daily basis central banks have to ensure by means of suitable tools the continuous supply of missing liquidity to the banking system so that banks could meet their obligations by virtue of minimum reserves. In addition, central banks must take into account the influence of autonomous factors such as unstable demand of clients for currency in circulation and volatility of balances on the state budget account that cause daily fluctuations in the volume of the banking system liquidity. In a longer run central banks have to cope with increasing demands of the banking system on the supplies of liquidity due to the trend growth of bank demand for reserves. Central banks have to primarily react to an increasing volume of minimum reserves in connection with the trend growth of the volume of deposits in the banking system on which the calculation of minimum reserves is based. Besides, central banks have to accommodate the supply of liquidity to the permanently growing demand for currency in circulation by clients because currency is technically issued to the debit of bank reserves with central bank.

As seen from the above-mentioned considerations, under normal circumstances there is a quantitatively significant dependence of the banking system on liquidity supplied by central bank. In countries with the long-term excess of liquidity central bank had to permanently supply a quantitatively large volume of liquidity on another than credit basis in the past. The source of this liquidity may be e.g. the entry of central bank capital into the banking system or the repurchase of assets of banks by central bank to solve the problems of solvency of these banks. Central bank's interventions in the foreign exchange market are another possibility: purchase of foreign currency in order to weaken the domestic currency and/or to decelerate the trend appreciation of domestic currency. In both cases these 
factors are typical of developments in transition economies: it may be either the government's significant activity during the banking sector transformation or fears of central banks from the rapid appreciation of domestic currency with regard to the export orientation of these economies.

\section{THE MECHANISM OF STABILISATION OF O/N INTEREST RATES}

We assume that at a time $t$ agents in the money market compare the actual size of quoted $n$-day interest rate with the expected future development of $\mathrm{O} / \mathrm{N}$ interest rates in the run of subsequent $n$ days while with longer contract maturity they claim an increasing sufficient reward in the form of term premium. Resultant equilibrium can be expressed as the equilibrium of a speculator who on the basis of available information $\left(\Omega_{\mathrm{t}}\right)$ quotes actual $n$-day interest rate $\left(\mathrm{IR}_{\mathrm{t}}^{\mathrm{n}}\right)$ as the sum of the expected average level of $\mathrm{O} / \mathrm{N}$ rates in the period $t$ to $t+k$ $\left(\operatorname{IR}_{\mathrm{t}}^{\mathrm{O} / \mathrm{N}, \mathrm{e}}, \operatorname{IR}_{\mathrm{t}+1}^{\mathrm{O} / \mathrm{N}, \mathrm{e}}, \ldots, \operatorname{IR}_{\mathrm{t}+\mathrm{k}}^{\mathrm{O} / \mathrm{e}}\right)$ and term premium $\left(\rho_{\mathrm{t}}^{\mathrm{n}}\right)$ :

$\operatorname{IR}_{\mathrm{t}}^{\mathrm{n}}=\frac{1}{\mathrm{n}} \sum_{\mathrm{k}=0}^{\mathrm{n}-1} \operatorname{IR}_{\mathrm{t}+\mathrm{k}}^{\mathrm{O} / \mathrm{N}, \mathrm{e}} \Omega_{\mathrm{t}}+\rho_{\mathrm{t}}^{\mathrm{n}}$

We assume that central bank uses announced $s$-day interest rate $\left(\operatorname{IR}_{\mathrm{CB}, \mathrm{t}}^{\mathrm{s}}\right)$ in the position of the main policy rate. In case main policy rate is represented by market $\mathrm{O} / \mathrm{N}$ interest rate, the announced level of main policy rate usually corresponds to the average of effective $\mathrm{O} / \mathrm{N}$ interest rates in the run of several trade days. On the contrary, if main policy rate is a specific interest rate that is exclusively used in monetary operations of central bank and its maturity is longer than one day, then the announced level of main policy rate usually corresponds to the limit (minimum or maximum) level of effective interest rates in periodic tenders for the supply or withdrawal of liquidity.

The mechanism stabilising ultra-short interest rates is understood as a continuous process resulting in the situation when the average level of ultra-short interest rates copies the course of main policy rate while quantitatively more significant deviations of these rates from main policy rate are of transient character only. This process can be described as the situation when agents in the money market are convinced that the average spread between expected $\mathrm{O} / \mathrm{N}$ interest rates and the actual and expected future level of main policy rate will approach zero in the run of future $n$ days:

$$
\frac{1}{\mathrm{n}} \sum_{\mathrm{k}=0}^{\mathrm{n}-1}\left(\operatorname{IR}_{\mathrm{t}+\mathrm{k}}^{\mathrm{O} / \mathrm{N}, \mathrm{e}}-\mathrm{IR}_{\mathrm{CB}, \mathrm{t}+\mathrm{k}}^{\mathrm{s}, \mathrm{e}}\right) \mid \Omega_{\mathrm{t}}=\mathrm{p}, \mathrm{p} \rightarrow 0
$$

With the existence of deposit and lending facilities it is possible to identify relatively accurately the lower and upper limits of fluctuations of expected $\mathrm{O} / \mathrm{N}$ interest rates and to estimate a minimum extent of volatility of the spread between expected $\mathrm{O} / \mathrm{N}$ interest rate and main policy rate. From the aspect of $\mathrm{O} / \mathrm{N}$ interest rate dynamics it is to assume that these rates will fluctuate more or less symmetrically around main policy rate in relation to day-to-day changes in the relations between the central bank's supply of reserves and aggregate demand of banks for reserves. The volatility of $\mathrm{O} / \mathrm{N}$ interest rates is influenced by the fact that the supply of central bank's reserves is based on a prediction of the demand function and during the trade day the money market is hit by liquid shocks connected with changes in autonomous demand for reserves that can influence the actual volume of the banking system liquidity.

\section{THE DYNAMICS OF O/N INTEREST RATES IN THE CONTEXT OF THE FUNCTIONS OF DEMAND FOR RESERVES AND SUPPLY OF RESERVES}

The dynamics of $\mathrm{O} / \mathrm{N}$ interest rates is substantially influenced by the duty of banks to hold minimum reserves on their accounts of reserves with central bank (see e.g. Bindseil, Seitz, 2001; Prati, Bartolini, Bertola, 2002 or Gaspar, Quirós, Mendizábal, 2004). As the daily balances on this account need not correspond to the prescribed level of minimum reserve requirement, in their creation banks may consider the problem of the costs of holding of minimum reserve requirement. In this context Hamilton (1996), Taylor (2001) or Bartolini, Bertola, Prati (2001 and 
2002) discussed a simple model of demand for reserves in which banks carry out intertemporal substitution of demand for reserves aimed at minimisation of the costs of holding of reserves. Banks restrict the holding of reserves at days when conditions in the money market are characterised by relatively high demand for reserves and so their price is temporarily high, in favour of days with excess liquidity in the market when reserves are cheaper. In this model agents in the money market speculate for expected movements of $\mathrm{O} / \mathrm{N}$ interest rate between any two consecutive trade days and they increase (decrease) their actual demand for reserves above (below) the level of minimum reserve requirement in relation to an expected increase (decrease) in $\mathrm{O} / \mathrm{N}$ interest day at the next trade day.

The result of such consideration is a change in the relations between demand and supply in the money market that will immediately be reflected in variations in actual $\mathrm{O} / \mathrm{N}$ interest rate. The expectation of a decrease (increase) in tomorrow's $\mathrm{O} / \mathrm{N}$ interest rate leads to a decrease (increase) in actual $\mathrm{O} / \mathrm{N}$ interest rate. Under equilibrium in the money market it holds good that the actual level of $\mathrm{O} / \mathrm{N}$ interest rate corresponds to its expected tomorrow's level:

$$
\operatorname{IR}_{\mathrm{t}}^{\mathrm{O} / \mathrm{N}}=\mathrm{IR}_{\mathrm{t}+1}^{\mathrm{O} / \mathrm{N}, \mathrm{e}} \mid \Omega_{\mathrm{t}}
$$

The above-mentioned condition does not hold good in all circumstances. The presented model was derived from operations in the U.S money market where the price of reserves traded in the daily open market operations with overnight maturity basically corresponds to the actual level of $\mathrm{O} / \mathrm{N}$ interest rate. In the case of central banks that use "non-market" main policy rate with longer than overnight maturity not only the absolute price of resources in the money market is important but also the relation between the price of resources in the money market and the effective price of resources acquired or deposited with central bank through the open market operations with less than daily frequency, i.e. the spread between $\mathrm{O} / \mathrm{N}$ interest rate and effective main policy rate. In such a case the demand for central bank's liquidity (supply of excess liquidity) is based not only on current need of reserves but also it is formed in the context of demands on reserves in the horizon of the maintenance period or in the horizon of the maturity date of open market operations. The outcome of the tender for liquidity supply/withdrawal also gives retroactively an impulse for the accommodation of $\mathrm{O} / \mathrm{N}$ interest rate by an explicit expression of the effective price of liquidity traded between central bank and other banks (Demiralp, S., Jordá, O., 2002).

If the spread between the expected $\mathrm{O} / \mathrm{N}$ interest rate and effective main policy rate at an actual day is positive, the banks may evaluate resources in the money market as "too expensive", and on the contrary, if this spread is negative, the reserves may seem to be "too cheap". The expected decrease in the positive (negative) spread between two trade days may therefore imply that banks will tend to increase (decrease) temporarily the actual demand for reserves of central bank and they will try to decrease (increase) the balance on the account of reserves below (above) the level corresponding to minimum reserve requirement. In this case equilibrium in the money market is defined as the specific situation when the size of the expected spread between $\mathrm{O} / \mathrm{N}$ interest rate and effective main policy rate for the actual day corresponds to the size of the expected spread between both interest rates for the next trade day while both spreads equal the above defined average spread $p$ :

$$
\left(\operatorname{IR}_{t}^{\mathrm{O} / \mathrm{N}, \mathrm{e}}-\mathrm{IR}_{\mathrm{CB}, \mathrm{t}}^{\mathrm{s}}\right)\left|\Omega_{\mathrm{t}}=\left(\mathrm{IR}_{\mathrm{t}+1}^{\mathrm{O} / \mathrm{N}, \mathrm{e}}-\mathrm{IR}_{\mathrm{CB}, \mathrm{t}+1}^{\mathrm{s}, \mathrm{e}}\right)\right| \Omega_{\mathrm{t}}=\mathrm{p}
$$

It has been documented (see e.g. Hamilton, 1996; ECB, 2002; Gaspar, Quirós, Mendizábal, 2004; FRBNY 2008 or Prati, Bartolini, Bertola, 2002) that the sign of the spread between $\mathrm{O} / \mathrm{N}$ interest rates and main policy rate and/or the variations in $\mathrm{O} / \mathrm{N}$ interest rates are sometimes easy to predict. It is in contradiction with the above condition of equilibrium. In fact, the intertemporal substitution of reserves is not strong enough to suppress systematic features in the behaviour of $\mathrm{O} / \mathrm{N}$ interest rates. In connection with possible predictability of $\mathrm{O} / \mathrm{N}$ interest rate movements so called calendar effects are mentioned most frequently when $\mathrm{O} / \mathrm{N}$ interest rates vary according to a certain day in the calendar on which a specific trade day falls (e.g. the last or the first working day of the week, month etc.). In addition, a systematic increase in the size and variability of the spread between $\mathrm{O} / \mathrm{N}$ interest rates and main policy rate is identified on some markets at the last days of the maintenance period. 
One of the reasons why predictable movements of the spread between $\mathrm{O} / \mathrm{N}$ interest rates and main policy rate persist may be that the main motive of banks in trading in the money market is to continuously hold reserves that in the context of individual and aggregate liquid shocks will enable the bank to cope with fluctuations in the need of reserve resources in the course of trade day. The problem of purely individual liquid shocks consists in the necessity of clearing payments of banks within the interbank payments system. Hence it does not have an immediate impact on the level of aggregate demand for reserves by its character. However, full dependence of banks on external liquid resources may be too risky because it makes banks trade in the money market even if the situation is not favourable. It may lead to a sort of prudence of banks and to the holding of a "standby reserve" on the account of reserves that will reduce their potential for speculations for day-to-day movements of $\mathrm{O} / \mathrm{N}$ interest rates.

So called autonomous factors of demand for reserves in the form of variable demand of the public for money in circulation and in the form of variances in flows in the state budget are also crucial for movements of $\mathrm{O} / \mathrm{N}$ interest rates. In both cases changes in the aggregate balance on the accounts of bank reserves with central bank take place, and from the aspect of banks the need for reserve resources is changed. As indicated by Bindseil and Seitz (2001), ECB (2008) and FRBNY (2008), mainly the prediction of daily volume of government operations is difficult for central banks. A variance between the expected and actual development of net government revenues within a trade day may therefore become a potentially important source of instability of $\mathrm{O} / \mathrm{N}$ interest rates.

In case of minimum reserve requirement it is obvious (see e.g. ECB, 2001; FRBNY, 2008) that the holding of bank reserves with central bank is not fluent in the maintenance period; in the first phase of the maintenance period the average balance on the account of reserves is often below the level of minimum reserve requirement while in the second phase of the maintenance period banks significantly increase their demand for reserves. Therefore in the first phase of the maintenance period the size and volatility of the spread between $\mathrm{O} / \mathrm{N}$ interest rates and main policy rate is very low (see e.g. Prati, Bartolini, Bertola, 2002).

In the second phase of the maintenance period a deficit of liquidity frequently occurs in the banking system. Banks are obliged to accumulate larger volumes of reserves by virtue of minimum reserve requirement. It is not so easy to counterbalance negative liquid shocks by a decrease in the resources on the account of reserves because a failure to meet central bank's requirement for minimum reserves and the duty to pay respective penalties are imminent. For this reason it is quite logical that banks try to increase their balance on the account of reserves above the minimum reserve requirement, so avoiding actively the situation when they would not have a sufficient volume of reserves at disposal as a result of aggregate liquid shock. A high demand for reserves may cause that at the end of the maintenance period conditions for the creation of reserves will deteriorate substantially, i.e. the average and volatility size of the spread between $\mathrm{O} / \mathrm{N}$ interest rates and main policy rate will increase.

The intensity of $\mathrm{O} / \mathrm{N}$ interest rate movements is also significantly dependent on the extent to what central bank accommodates the supply of reserves to the systematic changes in the aggregate demand for reserves. Central banks usually declare a concern to accommodate their supply of reserves according to the movements of demand for reserves. Their target is not to permit that as a result of the instability of demand for reserves there would be a quantitatively significant deficit or excess of liquidity in the money market that would destabilise the movements of $\mathrm{O} / \mathrm{N}$ interest rate. The supply of reserves is usually conducted with the aim to accommodate changes in the demand for reserves ensuing from the assumed dynamics of balances due to minimum reserve requirement and from the influence of autonomous liquid shocks. From the aspect of variations in $\mathrm{O} / \mathrm{N}$ interest rates it is crucial whether central banks fully respond to the concern of banks to create excess reserves. The existing calendar effects and pressures on an increase in $\mathrm{O} / \mathrm{N}$ interest rates at the end of the maintenance period suggest that central banks apparently satisfy only a portion of the demand for excess reserves.

\section{ECONOMETRIC MODEL OF THE DYNAMICS OF O/N INTEREST RATES WITHIN THE DEMAND FOR RESERVES AND SUPPLY OF RESERVES}

We assume that aggregate demand of banks for reserves $\left(R_{t}^{D}\right)$ and supply of reserves of central bank $\left(R_{t}^{S}\right)$ are functions of these factors: 


$$
\begin{aligned}
& \mathrm{R}_{\mathrm{t}}^{\mathrm{D}}=\mathrm{MRR}_{\mathrm{t}}^{\mathrm{D}, \mathrm{e}}+\mathrm{ER}_{\mathrm{t}}^{\mathrm{D}, \mathrm{e}}+\mathrm{AF}_{\mathrm{t}}^{\mathrm{D}, \mathrm{e}}+\mathrm{OMO}_{\mathrm{t}-\mathrm{k}}+\alpha\left[\left(\mathrm{IR}_{\mathrm{t}}^{\mathrm{D}, \mathrm{O} / \mathrm{N}, \mathrm{e}}-\mathrm{IR}_{\mathrm{CB}, \mathrm{t}}^{\mathrm{s}}\right)-\left(\mathrm{IR}_{\mathrm{t}+1}^{\mathrm{D}, \mathrm{O} / \mathrm{N}, \mathrm{e}}-\mathrm{IR}_{\mathrm{CB}, \mathrm{t}+1}^{\mathrm{D}, \mathrm{s}, \mathrm{e}}\right)\right]+\mathrm{u}_{\mathrm{t}} \\
& \mathrm{R}_{\mathrm{t}}^{\mathrm{S}}=\mathrm{MRR}_{\mathrm{t}}^{\mathrm{S}, \mathrm{e}}+\mathrm{ER}_{\mathrm{t}}^{\mathrm{S}, \mathrm{e}}+\mathrm{AF}_{\mathrm{t}}^{\mathrm{S}, \mathrm{e}}+\mathrm{OMO}_{\mathrm{t}-\mathrm{k}}+\beta\left(\mathrm{IR}_{\mathrm{t}}^{\mathrm{S}, \mathrm{O} / \mathrm{N}, \mathrm{e}}-\mathrm{IR}_{\mathrm{CB}, \mathrm{t}}^{\mathrm{s}}-\mathrm{p}\right)+\mathrm{v}_{\mathrm{t}}
\end{aligned}
$$

where $\mathrm{MRR}_{\mathrm{t}}^{\mathrm{D}, \mathrm{e}}$ and $\mathrm{MRR}_{\mathrm{t}}^{\mathrm{S}, \mathrm{e}}$ express the expectations of banks and central bank concerning the closing balance on the account of reserves for the purposes of satisfaction of minimum reserve requirement for a given trade day $t$, $\mathrm{ER}_{\mathrm{t}}^{\mathrm{D}, \mathrm{e}}$ and $\mathrm{ER}_{\mathrm{t}}^{\mathrm{S}, \mathrm{e}}$ are the expectations of banks and central bank concerning the level of excess reserves, $\mathrm{AF}_{\mathrm{t}}^{\mathrm{D}, \mathrm{e}}$ and $\mathrm{AF}_{\mathrm{t}}^{\mathrm{S}, \mathrm{e}}$ are the expectations of banks and central bank concerning the influence of autonomous factors, $\mathrm{OMO}_{\mathrm{t}-\mathrm{k}}$ is the volume of the open market operations with $k$-day maturity, the maturity of which falls on actual day, $\alpha(\alpha>0)$ is the parameter of the sensitivity of demand for reserves to the change in the spread between $\mathrm{O} / \mathrm{N}$ interest rate and effective main policy rate expected by banks $\left[\left(\operatorname{IR}_{\mathrm{t}}^{\mathrm{D}, \mathrm{O} / \mathrm{N}, \mathrm{e}}-\mathrm{IR}_{\mathrm{CB}, \mathrm{t}}^{\mathrm{s}}\right)-\left(\mathrm{IR}_{\mathrm{t}+1}^{\mathrm{D}, \mathrm{O} / \mathrm{N}, \mathrm{e}}-\mathrm{IR}_{\mathrm{CB}, \mathrm{t}+1}^{\mathrm{D}, \mathrm{s}, \mathrm{e}}\right)\right], \beta$ $(\beta>0)$ is the parameter of the sensitivity of supply of reserves to the deviation of $\mathrm{O} / \mathrm{N}$ interest rates from main policy rate expected by central bank $\left(\mathrm{IR}_{\mathrm{t}}^{\mathrm{S}, \mathrm{O} / \mathrm{N}, \mathrm{e}}-\mathrm{IR}_{\mathrm{CB}, \mathrm{t}}^{\mathrm{s}}-\mathrm{p}\right)$ for actual day, while the values $\beta$ are influenced by the intensity of direct stabilisation of $\mathrm{O} / \mathrm{N}$ interest rates carried out by central bank and by its willingness to cover changes in the demand for reserves by virtue of speculations of banks for variations in $O / N$ interest rates, $u_{t}$ and $v_{t}$ are random errors with zero mean and constant volatility.

The differences between central bank's supply of and bank's demand for liquidity can be expressed as this function:

$$
\begin{aligned}
& \left(\mathrm{R}_{\mathrm{t}}^{\mathrm{S}}-\mathrm{R}_{\mathrm{t}}^{\mathrm{D}}\right)=\left(\mathrm{MRR}_{\mathrm{t}}^{\mathrm{S}, \mathrm{e}}-\mathrm{MRR}_{\mathrm{t}}^{\mathrm{D}, \mathrm{e}}\right)+\left(\mathrm{ER}_{\mathrm{t}}^{\mathrm{S}}-\mathrm{ER}_{\mathrm{t}}^{\mathrm{D}, \mathrm{e}}\right)+\left(\mathrm{AF}_{\mathrm{t}}^{\mathrm{S}, \mathrm{e}}-\mathrm{AF}_{\mathrm{t}}^{\mathrm{D}, \mathrm{e}}\right)+\beta\left(\mathrm{IR}_{\mathrm{t}}^{\mathrm{S}, \mathrm{O} / \mathrm{N}, \mathrm{e}}-\mathrm{IR}_{\mathrm{CB}, \mathrm{t}}^{\mathrm{s}}-\mathrm{p}\right)- \\
& -\alpha\left[\left(\operatorname{IR}_{\mathrm{t}}^{\mathrm{D}, \mathrm{O} / \mathrm{N}, \mathrm{e}}-\mathbb{I}_{\mathrm{CB}, \mathrm{t}}^{\mathrm{s}}\right)-\left(\mathrm{IR}_{\mathrm{t}+1}^{\mathrm{D}, \mathrm{O} / \mathrm{N}, \mathrm{e}}-\mathrm{IR}_{\mathrm{CB}, \mathrm{t}+1}^{\mathrm{D}, \mathrm{s}, \mathrm{e}}\right)\right]+\left(\mathrm{v}_{\mathrm{t}}-\mathrm{u}_{\mathrm{t}}\right)
\end{aligned}
$$

We assume that these differences are partly random containing different views of central bank and banks on satisfaction of minimum reserve requirement, the influence of autonomous factors and expectations of $\mathrm{O} / \mathrm{N}$ interest rate development, and partly systematic due to differences in central bank's view on the satisfaction of bank's demand for the excess reserves and in the form of central bank's low sensitivity to speculative changes in the demand for reserves. We consider a change in the spread between $\mathrm{O} / \mathrm{N}$ interest rates and main policy rate to be the function of aggregate liquidity prediction errors. Besides, we assume that it is possible to identify calendar effects and the effect of the maintenance period first or last day. We also think that variations in the spread between these interest rates may show some features of autoregression process because differences in liquidity supply and demand may be correlated serially but they need not necessarily require the use of deposit or lending facility. As we are not able to acquire any information on the expected level of $\mathrm{O} / \mathrm{N}$ interest rates, we will leave the question about the influence of bank speculations for movements of $\mathrm{O} / \mathrm{N}$ interest rates only in the sphere of theoretical speculations. We take the variations in the spread between $\mathrm{O} / \mathrm{N}$ interest rates and main policy rate as the function of these factors:

$$
\Delta\left(\mathrm{IR}_{\mathrm{t}}^{\mathrm{O} / \mathrm{N}}-\mathrm{IR}_{\mathrm{CB}, \mathrm{t}}^{\mathrm{s}}\right)=\sum_{\mathrm{q}=1}^{\mathrm{r}} \lambda_{\mathrm{q}} \Delta\left(\mathrm{IR}_{\mathrm{t}-\mathrm{q}}^{\mathrm{O} / \mathrm{N}}-\mathrm{IR}_{\mathrm{CB}, \mathrm{t}-\mathrm{q}}^{\mathrm{s}}\right)+\pi\left(\mathrm{R}_{\mathrm{t}}^{\mathrm{S}}-\mathrm{R}_{\mathrm{t}}^{\mathrm{D}}\right)+\sigma^{\mathrm{i}} \mathrm{D}^{\mathrm{i}}+\sum_{\mathrm{j}}^{\mathrm{J}} \sigma_{\mathrm{j}}^{\mathrm{i}} \mathrm{D}_{\mathrm{j}}^{\mathrm{i}}+\mathrm{e}_{\mathrm{t}}
$$

where $\sum_{\mathrm{q}=1}^{\mathrm{r}} \lambda_{\mathrm{q}} \Delta\left(\mathrm{IR}_{\mathrm{t}-\mathrm{q}}^{\mathrm{O} / \mathrm{N}}-\mathrm{IR}_{\mathrm{CB}, \mathrm{t}-\mathrm{q}}^{\mathrm{s}}\right)$ expresses the autoregression process of variations in the spread between $\mathrm{O} / \mathrm{N}$ interest rate and main policy rate of $r$-th degree, $\lambda_{\mathrm{q}}\left(-1<\lambda_{\mathrm{q}}<1\right)$ are the parameters of this process, $r$ expresses the rate of inertia of the change in the spread between $\mathrm{O} / \mathrm{N}$ interest rates and main policy rate, $\pi(-1<\pi<1)$ measures the sensitivity of the spread change to the actual error of liquidity prediction, $\mathrm{D}^{\mathrm{i}}$ is dummy variable assuming the value one in case that the actual trade day falls on the $i$-th day of the maintenance period $(i=1, \ldots, I), I$ is the number of days in the maintenance period, $\sigma^{\mathrm{i}}$ expresses the intensity of the influence of the $\mathrm{i}$-th day in the 
maintenance period on the change in the spread between $\mathrm{O} / \mathrm{N}$ interest rates and main policy rate, $\mathrm{D}_{\mathrm{j}}^{\mathrm{i}}$ is dummy variable assuming the value one in case that at the $i$-th day of the maintenance period it is actual to consider the $j$-th calendar effect $\left(j=1, \ldots, J\right.$, where $J$ expresses the number of different calendar effects), $\sigma_{j}^{i}$ measures the intensity of the influence of the $j$-th calendar effect on the change in the size of the spread between these interest rates and $e_{t}$ is the random term.

\section{MANAGEMENT OF LIQUIDITY OF THE CZECH BANKING SYSTEM BY CZECH NATIONAL BANK}

Unlike the other banking systems the Czech banks work with overall liquidity surplus. The banking sector was manoeuvred in this situation due to the high activity of CNB in the stabilization of the Czech crown exchange rate through interventions in the foreign exchange market that prevented the appreciation of Czech crown. This policy was used within the system of the fixed exchange rate (by mid-1997) and subsequently in the system of managed exchange rate. Mainly indirect interventions were undertaken when CNB repurchased the government's privatisation incomes directly into foreign currency reserves. Only a smaller portion of excess liquidity of banks was issued as a part of the stabilization programme for the rescue of domestic banks in the nineties (see increased liquidity withdrawn in Figure 1).

Open market operations are managed in the form of repo operations which are agreements between CNB and other banks about securing the claim of a bank against CNB by transfer of debt securities. Repo operations are carried out in the form of repo tenders of American type: CNB demands liquidity in the money market and banks make bids to deposit excess reserves with CNB. CNB invites a repo tender on Monday, Wednesday and Friday (till May 2006 the tenders were organized on daily basis) at about $9.30 \mathrm{a} . \mathrm{m}$. In response, banks submit their orders to create a deposit with CNB. The results of repo tender are announced regularly at $10.00 \mathrm{a} . \mathrm{m}$. The repo tender of CNB is a special form of auction with variable interest rate and total volume of withdrawn liquidity not known to banks in advance, giving banks an opportunity for making their bids to CNB to create a deposit with fixed fortnight maturity. In submitting their orders banks specify not only the amount but also the required price of reserves to be deposited with CNB. The required interest rate is limited from above by the level of announced repo rate.

Figure 1: Amount of liquidity withdrawn through repo tenders (daily data)

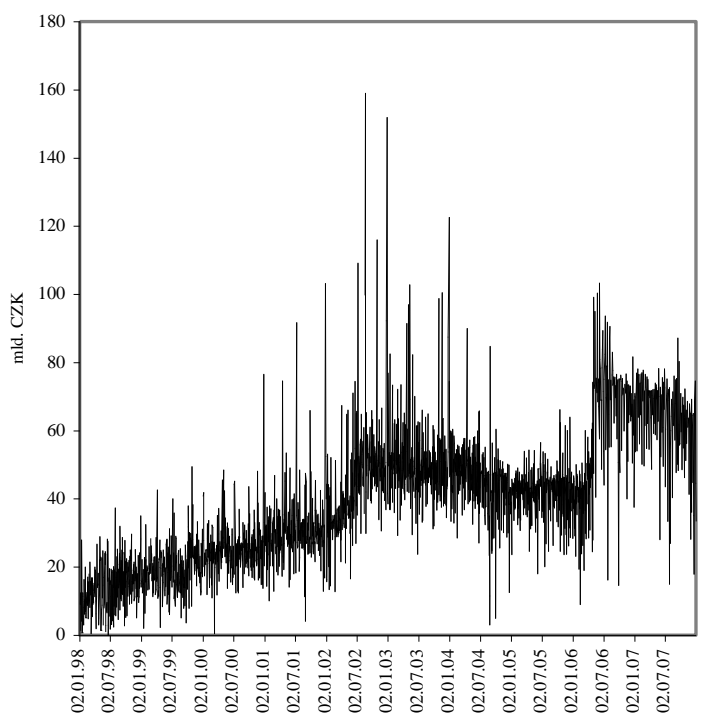

Figure 2: Minimum reserves requirement and balances on bank's reserve account with CNB (daily data)

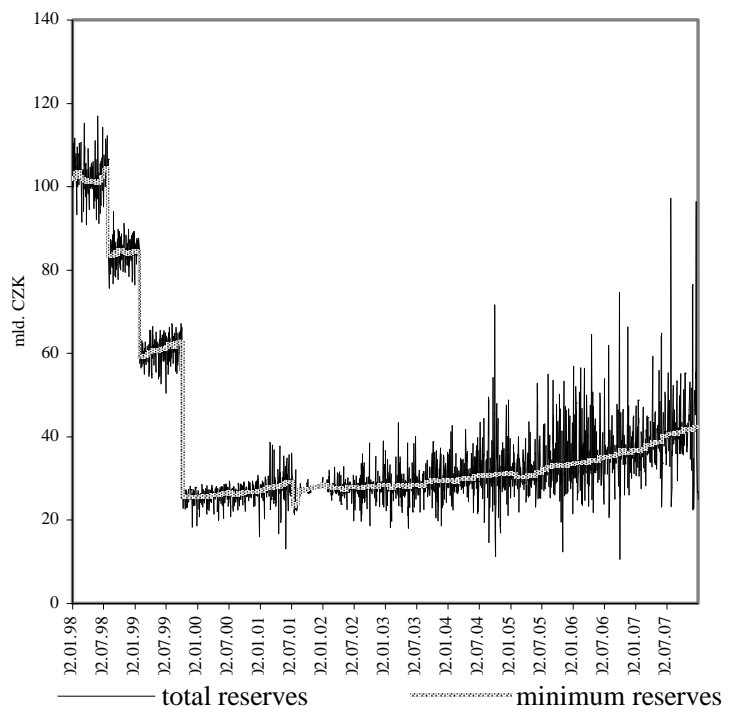

Source: CNB 
In the prediction of the volume of excess liquidity CNB takes into account a daily prognosis of demand for liquidity in the interbank market, i.e. CNB estimates the influence of factors with target prediction of the banking system liquidity at the end of the day concerned. Besides the terminated repo operations and the need of banks to replenish required minimum reserves it is mainly the estimation of the influence of autonomous factors such as government's operations on the account with CNB and issuance of currency in circulation. Figure 3 documents that as a result of unexpected autonomous shocks the forecasted volume of liquidity is usually different from the actual volume at the end of the day (error of the liquidity volume prediction). The average prediction error of liquidity volume amounts to -346 mio. CZK. Standard deviation is 4.47 billion CZK. As for the standard deviation, the volatility of errors of the liquidity volume prediction seems to be significantly higher in the first half of the observed period. The existence of the series correlation of errors of the liquidity volume prediction is also well identifiable while the time series of liquidity prediction errors is $\mathrm{AR}(2)$ process.

Figure 3: Error of liquidity volume prediction (daily data)

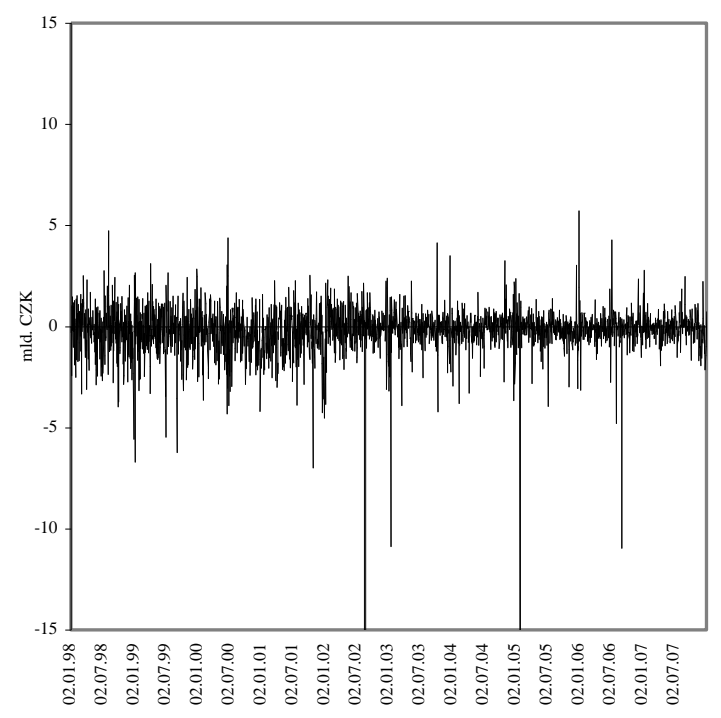

Figure 4: Differences between OMO target and liquidity supplied by banks in repo tenders (daily data)

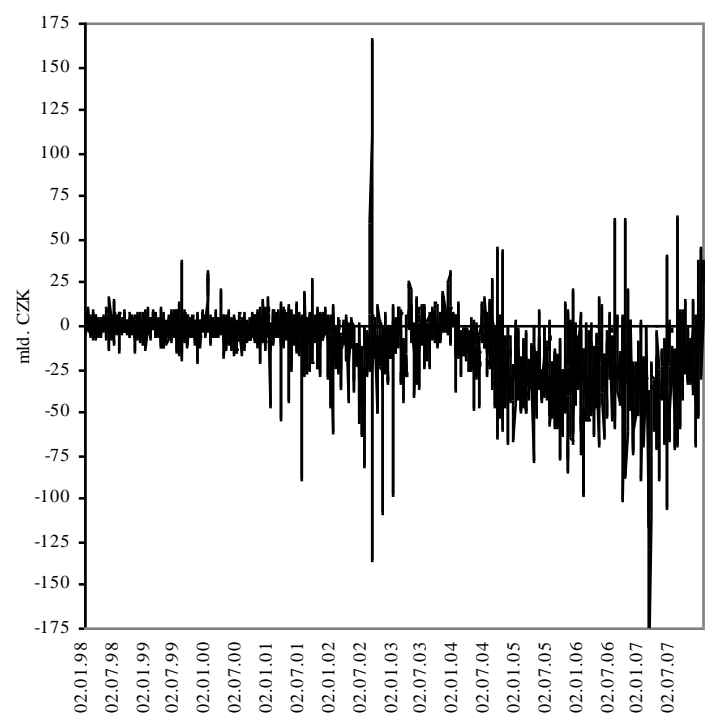

Source: CNB

In the examined period 1998-2007 in total 2513 tenders were performed absorbing the excess liquidity from the money market. Before a repo tender CNB defines a target for the repurchase of liquidity from banks (so called OMO target) with regard to required minimum reserves and expected changes in liquidity volume due to the influence of autonomous factors. CNB sets the OMO target in such a way that it will allow banks to comply with the prescription of required minimum reserves in relation to expected changes in liquidity caused by autonomous factors. In the framework of the OMO target CNB does not rely on bank's demand for excess reserves. During repo tenders there naturally arises a difference between the bid of liquidity volume on the part of banks and the OMO target. This difference may be influenced by the intensity with which banks are bidding to a repo tender a higher volume of liquidity than the actually existing one; it is also connected with the strategy of banks in the formation of required minimum reserves at the beginning or end of the maintenance period or it may be influenced by a different estimation of the influence of autonomous factors, especially by bank demand for currency in circulation.

The analysis of differences between OMO target and supplied liquidity shows that data in the examined period can be divided into three subsets in which prediction errors have different statistical characteristics. In 19982000 prediction errors are relatively small and they are distributed very close to zero (average error is 94 mio. CZK). The variability of prediction errors is relatively low and the frequency of extreme values is also low (standard error is 6,343 bil. CZK). Distribution of frequencies is almost perfectly symmetric with relatively higher frequency of 
values close to the average error of prediction (skewness is $-0,014$ and curtosis 7,509). The analysis of the sampling partial autocorrelation function indicates that the process generating the time series of liquidity prediction errors is $\mathrm{AR}(0)$ process (prediction errors are random and are not correlated serially).

Beginning with 2001 the differences between OMO target and supplied liquidity increase markedly and are not concentrated in the proximity of the zero any longer (CNB sees the supply of excess liquidity bellow the real one) (average daily difference is $-6,3$ bil. CZK). Statistical significance of the change of the average difference is confirmed on $1 \%$ significance level e.g. by Mann-Whitney test (the absolute value of the test criterion $z$ is 11.608). Simultaneously, the variability of these differences also increases markedly (standard error increses to 17,241 bil. $\mathrm{CZK})$. There is aleso an increase in the frequency of extreme values. The symmetry of frequency of distribution around the mean does not change significantly (skewness is about 0,04 ), but the kurtosis of distribution increases to 23,5). Moreover, the analysis of the partial autocorrelation function indicates that the process generating liquidity prediction errors is turned into $\mathrm{AR}(1)$ process.

These tendencies have been strengthened since 2004 while the average difference between OMO target and the bid of excess liquidity has increased to -25 bil. CZK and the volatility of differences has grown to 23.3 bil. CZK. Symmetry of the frequency of distribution has partly been disturbed (skewness -0.807) and distribution curtosis has dropped steeply (curtosis attains the level 5.720). The partial autocorrelation function shows the deepening of the autocorrelation of differences between OMO target and the bid of excess liquidity when the process generating deviations seems to be process $\operatorname{AR}(3)$.

Changes in these characteristics in the money market are apparently closely connected with a rapid increase in the volume of withdrawn liquidity in 2001 and 2002. In the years in question the average level of excess reserves increased from ca. 250 bil. CZK in November 2000 to 500 bil. CZK in November 2002. The own reasons for systematic underestimation of excess liquidity supply could be explained by the fact that CNB latently tries to reduce the volume of withdrawn liquidity and to decrease the high interest costs of repo operations in this way. In this case the balance on the account of banks with CNB would be higher than it would correspond to the envisaged excess reserves of banks. Figure 2 however shows that beginning with the year 2001 there has not been a significant difference of the average total volume of reserves from the prescription of required minimum reserves because the average volume of reserves above the required minimum reserves is only 98 mio. CZK at the average prescription of required minimum reserves amounting to 28.3 bil. CZK.

The underestimation of the volume and volatility of the excess liquidity supply by CNB can mainly be seen in the concern of banks in as advantageous as possible deposition of the largest liquidity volume possible with central bank which stimulates banks to make aggressive bids of liquidity volume that exceeds the available volume of the banking system excess liquidity in order to deposit the maximum liquidity volume at a limit rate in the form of announced repo rate. It is possible to deduce from the dynamics of the spread between announced repo rate and minimum and/or average interest rate paid to CNB for withdrawn liquidity that contrary to the original plan many times repo tenders of CNB behave rather like tenders with fixed interest rate when the minimum and especially the average interest rate at which the liquidity of banks is withdrawn are in the close proximity of announced repo rate.

\section{ANALYSIS OF THE STABILISATION MECHANISM OF REPO TENDERS IN THE CZECH INTERBANK MARKET}

The dynamics of $\mathrm{O} / \mathrm{N}$ interest rates in the Czech money market is documented on an example of reference interest rates O/N PRIBOR and CZEONIA. O/N PRIBOR is calculated as the simple arithmetic mean of offer interest rates quoted by the most important market makers in the interbank market between 10.30 and 10.45 a.m. As the determination of the values of O/N PRIBOR begins with a 15-30 min delay after the results of repo tender were announced, it is to assume that the variations in O/N PRIBOR may reflect the immediate reaction of the money market to the difference between CNB's OMO target and bank's supply of liquidity. CZEONIA is the weighted arithmetic mean of interest rates of all unsecured overnight deposits placed by market-makers in an interbank market during the trade day. The rate is published after the interbank market closure at about 16.30 hours. The CZEONIA character suggests that it reflects the dynamics of liquidity volume during the trade day; it is possible to speculate on its volume from the values of liquidity prediction errors at the end of the trade day. This data indicates whether the 
banking system operated on a certain day after the realization of repo tender and all autonomous shocks with fundamental surplus or deficit of liquidity.

It is evident at a glance (see Figure 5) that the spread between O/N PRIBOR and repo rate was largely volatile in 1998 and in the first six months of 1999 and since mid 2006 while from about the last third of 1999 to mid 2006 period these rates were significantly stabilised close to the level of the announced repo rate. Decrease in volatility of the spread was obviously an immediate consequence of the introduction of so called intraday credit in the framework of which, beginning on 3 Aug. 1999, banks were given a possibility of using an interest-free lending facility from $\mathrm{CNB}$ during the trade day in the case of the lack of money on their accounts of reserves. It means that at a time gap between receipts and expenditure on the account of reserves during the trade day banks do not have to buy necessary resources in the interbank market but they can receive these resources from CNB. All resources used by banks during the trade day must be returned back to the account of CNB before the end of the trade day. If not, the intraday credit will automatically become an overnight lending facility. In case of increasing volatility of the spread in last two years this is the reducement of the frequency of repo tenders from daily to three per week frequency that caused this significant change in behaviour of the spread.

Figure 5: Spread between O/N PRIBOR and repo rate (daily data)

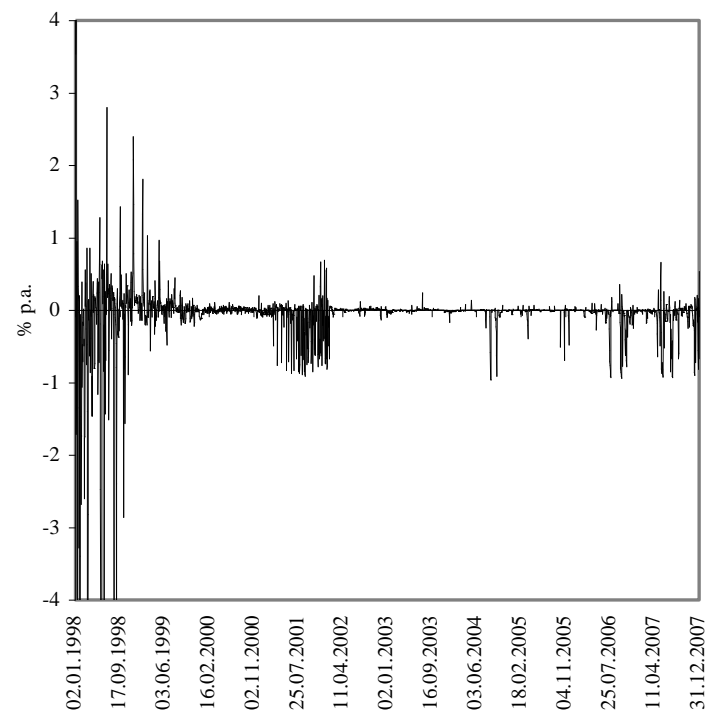

Figure 6: Spread between CZEONIA
and repo rate (daily data

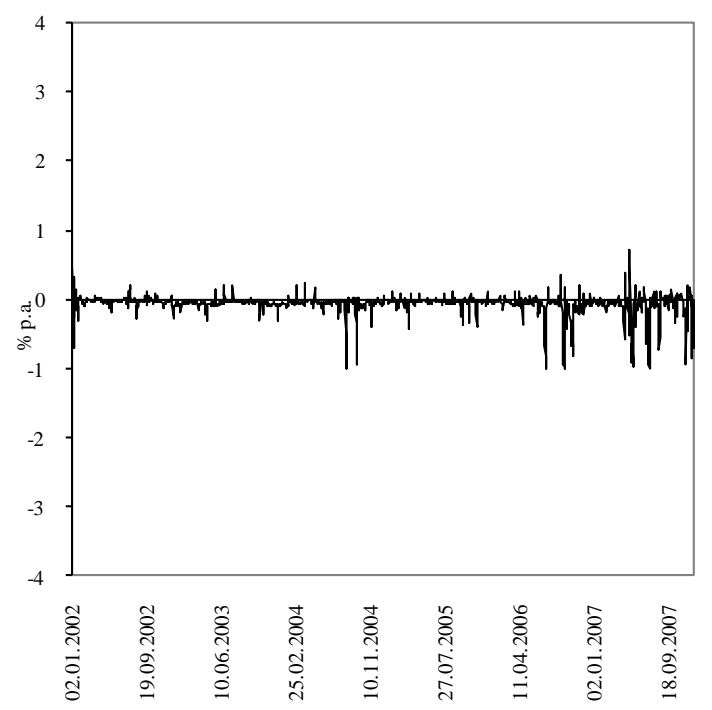

Source: CNB

Before the intraday credit was introduced, the average level of O/N PRIBOR was ca. 20 basis points below the level of repo rate. In this period there obviously occurred extreme deviations of O/N PRIBOR from repo rate, namely the great undershooting of repo rate in 1998. High variability in the spread between O/N PRIBOR and repo rate could also be identified clearly. The analysis of autocorrelation function and partial autocorrelation function indicates the existence of series autocorrelation and suggests that the process generating the spread between $\mathrm{O} / \mathrm{N}$ PRIBOR and repo rate is $\mathrm{MA}(3)$ process

With the introduction of intraday credit the average level of O/N PRIBOR approached the level of repo rate. According to Mann-Whitney test this movement is statistically significant on $1 \%$ significance level (the absolute value of the test criterion $z$ is 7.814). On the contrary, the extreme values of the spread do not exceed 100 basis points which is accompanied by a rapid decrease in the volatility of O/N PRIBOR deviations from repo rate. A decrease in the variability of the spread was reflected in an increase in the series autocorrelation of the spread between O/N PRIBOR and repo rate. 
In connection with a reduction of the frequency of repo tenders to three days per week there is an almost double increase in the volatility of the spread between O/N PRIBOR interest rate and repo rate. The increase in the spread volatility results in a decrease in the series autocorrelation of the spread while the process generating the spread is process AR(1). Besides the purely technical causes connected with an increase in the average volume of repo tenders the reasons for an increase in the spread volatility lie in CNB's limited capacities of management of the domestic banking system liquidity on a daily basis because CNB is losing an opportunity to react to the realized difference between OMO target and the supply of excess liquidity on days when no repo tenders are organized. As the CNB does not generally execute any fine-tuning operations during the day, the natural reaction of interbank market is that the variability of differences between OMO target and the supply of liquidity by banks and/or variability of unexpected autonomous liquid shocks is transmitted to a greater extent to the variability of the spread between O/N PRIBOR interest rate and repo rate.

The dynamics of the spread between CZEONIA interest rate and repo rate (see Figure 6) confirms that a reduction of the frequency of repo tenders has almost identical influences on the spread between CZEONIA interest rate and repo rate. Even though the reference interest rates O/N PRIBOR and CZEONIA are calculated by different methodology, they obviously show a high degree of correlation ( 0.86 for the second observed period beginning with $01 / 2002$ and 0.97 for the last observed period). CNB seems to be able to efficiently predict the influence of autonomous factors during the trade day because the conditions in the interbank market do not change fundamentally in the period between the settlement of repo tender and subsequent realization of autonomous liquid shocks. These results are due to the close cooperation of CNB with Ministry of Finance in the management of cash flow within the state budget as well as to the fact that the government's operations in the framework of the budget are not a source of significant autonomous shocks in the banking system liquidity because the government minimizes the balance on the budget account with CNB at the end of the trade day by flexible operations with treasury securities.

Table 2: Statistically significant parameters from equation $(8)$

\begin{tabular}{|c|c|c|c|c|c|c|c|}
\hline Spread & Period & $\mathbf{A R}(\mathbf{r})$ & $\begin{array}{c}\pi \\
\text { (st. e.) }\end{array}$ & $\begin{array}{c}\varsigma \\
\text { (st. e.) }\end{array}$ & $\begin{array}{c}\sigma^{\mathrm{i}} \\
\text { (st. e.) }\end{array}$ & $\begin{array}{c}\sigma_{j}^{i} \\
\text { (st. e.) }\end{array}$ & $\mathbf{R}^{2}$ \\
\hline \multirow{4}{*}{$\begin{array}{l}\text { O/N PRIBOR } \\
\text { - } \\
\text { REPO RATE }\end{array}$} & \multirow{2}{*}{$\begin{array}{l}01 / 1998 \\
\text { to } \\
07 / 1999\end{array}$} & \multirow{2}{*}{4} & \multirow{2}{*}{$\begin{array}{l}-0,038^{*} \\
(0,013)\end{array}$} & \multirow{2}{*}{-} & $\begin{array}{c}\sigma^{\text {BEGMAINT }} \\
0,440^{* *} \\
(0,211)\end{array}$ & \multirow[t]{2}{*}{ 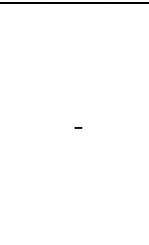 } & \multirow{2}{*}{0,36} \\
\hline & & & & & $\begin{array}{c}\sigma^{\text {ENDMAINT }} \\
-0,432^{* *} \\
(0,207)\end{array}$ & & \\
\hline & $\begin{array}{c}08 / 1999 \\
\text { to } \\
04 / 2006 \\
\end{array}$ & 8 & $\begin{array}{l}-0,0007^{*} \\
(0,0002)\end{array}$ & $\begin{array}{l}0,195^{* *} \\
(0,094)\end{array}$ & - & - & 0,99 \\
\hline & $\begin{array}{c}05 / 2006 \\
\text { to } \\
12 / 2007\end{array}$ & 3 & $\begin{array}{c}-0,0005^{* * *} \\
(0,0003)\end{array}$ & $\begin{array}{l}3,108^{*} \\
(0,315)\end{array}$ & - & - & 0,55 \\
\hline \multirow{3}{*}{$\begin{array}{l}\text { CZEONIA } \\
- \\
\text { REPO RATE }\end{array}$} & $01 / 2002$ & \multirow{2}{*}{8} & \multirow{2}{*}{$\begin{array}{c}0,0005^{* * *} \\
(0,0003)\end{array}$} & \multirow{2}{*}{$\begin{array}{l}0,128^{* * *} \\
(0,058)\end{array}$} & \multirow{2}{*}{$\begin{array}{c}\sigma^{\text {BEGMAINT }} \\
0,036^{*} \\
(0,010)\end{array}$} & $\begin{array}{c}\sigma^{\text {BEGMONTH }} \\
0,027^{*} \\
(0,010)\end{array}$ & \multirow{2}{*}{0,46} \\
\hline & $\begin{array}{c}\text { to } \\
04 / 2006\end{array}$ & & & & & $\begin{array}{c}\sigma^{\text {ENDYEAR }} \\
-0,067^{* * *} \\
(0,036)\end{array}$ & \\
\hline & $\begin{array}{c}05 / 2006 \\
\text { to } \\
12 / 2007 \\
\end{array}$ & 3 & 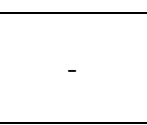 & $\begin{array}{c}3,369^{*} \\
(0,277)\end{array}$ & - & $\begin{array}{c}\sigma^{\text {ENDMONTH }} \\
0,103^{*} \\
(0,037)\end{array}$ & 0,41 \\
\hline \multicolumn{8}{|c|}{$\begin{array}{l}\sigma^{\text {BEGMAINT }} \text { or } \sigma^{\text {ENDMAINT }} \text { - parameter for the first or the last day of maintenance period } \\
\sigma^{\text {BEGMONTH }} \text { or } \sigma^{\text {ENDMONTH }} \text { - parameter for the first or last trade day in the month } \\
\sigma^{\text {ENDYEAR }}-\text { parameter for last trade day of the year } \\
*, * *, * * * \text { parameters statistically significant on } 1 \%, 5 \% \text { a } 10 \% \text { level of significance } \\
\text { Source } \text { my own calculation }\end{array}$} \\
\hline
\end{tabular}


Experiments with the estimations of regression parameters of the equation (8) confirm that changes in the spread between O/N PRIBOR interest rate and repo rate behave differently before and after the introduction of intraday credit (see Table 2). In the period before the introduction of intraday credit the effect of differences between OMO target and the supply of liquidity by banks and also the influence of calendar effects in the form of the beginning and end of the maintenance period appear statistically significant. The negative sign of the regression parameter in the difference between OMO target and the supply of liquidity by banks indicates that if banks underestimate (overestimate) the volume of liquidity supplied for various reasons compared to the volume of excess liquidity in the banking system, the interest rate will react to it by its decrease (increase) in relation to the announced level of repo rate. A problem of this estimation is that the regression parameters of calendar effects have opposite signs to our expectations. The reverse signs of parameters on the first and last day of the maintenance period can be explained by the overall surplus of liquidity in the domestic interbank market, i.e. banks can replenish the required minimum reserves from their "own resources" and do not have to borrow for them from CNB that causes that the O/N PRIBOR interest rates are usually pushed down.

The introduction of intraday credit into the set of CNB's instruments caused a sharp weakening of the influence of differences between OMO target and liquidity supply on the movements of the spread between $\mathrm{O} / \mathrm{N}$ PRIBOR interest rate and repo rate, and the loss of any systematic calendar effects at the same time. On the other hand, the sharp weakening of the spread volatility confirms that changes in repo rate have a systematic influence on the magnitude of the spread. It proves a certain informative content connected with CNB's monetary-policy decision and subsequent commentary of CNB representatives. Obviously, with a decrease in the spread volatility there is a significant increase in the spread inertia.

The estimation of an econometric model for the spread between CZEONIA interest rate and repo rate can provide almost the identical results. As prediction errors of liquidity volume are relatively low, while banks may know the magnitude of prediction error ex post, the influence of the prediction error of liquidity volume on the spread amounts to units of basis points. The value of parameter $\varsigma$ shows that the informative content of repo rate change diminishes during the day and is smaller than the instantaneous influence of repo rate change on the spread between O/N PRIBOR interest rate and repo rate. It is interesting to examine a variety of statistically significant calendar effects such as the beginning of the maintenance period and month and the end of the year. In all cases it implies the fine-tuning operation of the spread between CZEONIA interest rate and repo rate.

A reduction of the frequency of repo tenders to three days per week increases the spread volatility, limiting the importance of an autocorrelation component in the econometric model. The sensitivity of the spread between O/N PRIBOR interest rate and repo rate to differences between OMO target and the supply of excess liquidity is slightly diminished. However, there is a significant increase in the influence of repo rate change on the dynamics of the spread when the spread adjustment strongly overshoots repo rate changes. Such a strong informative effect of repo rate change may be connected with the fact that after a long time in the second half of 2006 and in 2007 CNB started to identify rapidly growing inflationary pressures in the economy accompanied by disequilibrium in the labour market and had to increase repo rate in order to cope with this situation. In its outlooks of the future dynamics of repo rate at that period CNB emphasized the effect of inflationary risks and high probability of a further increase in repo rate.

The influence of the prediction error of liquidity volume on the dynamics of the spread between CZEONIA interest rate and repo rate is beyond the standard level of statistical significance at that period. On the contrary, the influence of the informative effect of repo rate change seems to increase during the day, not to weaken like in the preceding period. The influence of calendar effects is very different whereas only the end of the month appears to be statistically significant in relation to the magnitude of the spread. But the estimation of the influence of calendar effects may be negatively biased by a reduction of the frequency of repo tenders because it is not guaranteed any longer that repo tenders will be held on all days that are considered as calendar effects.

\section{CONCLUSION}

In the present concept of monetary policy implementation central banks beleive that a mechanism stabilising $\mathrm{O} / \mathrm{N}$ interest rates in the proximity of main policy rate is the basic prerequisite to achieve set monetary 
targets. The function of stabilizing mechanism assumes that the volume of liquidity in the money market is held in line with the needs of banks, i.e. the supply of liquidity by central banks copies the demand of banks for reserve resources through the open market operations.

The study of basic theoretical approaches to determination of ultra-short interest rates showed that the elements of stabilisation of these rates were contained not only in the above described behaviour of central banks but also in changes in bank demand, mainly in the context of intertemporal substitution of reserves during the creation of minimum reserve requirement. We demonstrated in this contribution that the development of demand for reserves was fundamentally different when central bank ensured the stability of ultra-short interest rates through targeting of market interest rate from the situation when it used targeting of effective main policy rate by the open market operations.

The empirical analysis of the behaviour of O/N PRIBOR and CZEONIA interest rates explicitly proved CNB's ability to stabilise $\mathrm{O} / \mathrm{N}$ interest rates in the nearest proximity of repo rate. It also identified some structural changes acting in the money market. First of all, it was the introduction of intraday credit that significantly reduced the instability of demand for reserve resources in the interbank market and decreased the volatility of ultra-short interest rates. On the other hand, reduced frequency of repo tenders significantly increased volatility of the spread between $\mathrm{O} / \mathrm{N}$ interest rates on interbank market and repo rate. We also documented a relatively rapid increase in the volatility of differences between OMO target and bank's supply of excess reserves since 2001. It resulted in the weakening of a direct relationship between O/N PRIBOR and success of repo tenders.

\section{ACKNOWLEDGEMENT}

The Article is processed as an output of a research project 'Instability of Financial Markets and Efficiency of their Regulations, registered by Grant Agency of the Czech Republic under the registration number P402/10/0289 and Monetary and Regulatory Aspects of Instability of Financial Markets, registered by Internal Grant Agency of the University of Economics in Prague under the registration number F1/10/2010.

\section{AUTHOR INFORMATION}

Karel Bruna (bruna@vse.cz) - Associate Proffesor at Department of Monetary Theory and Policy at University of Economics in Prague in the Czech Republic. He works as lecturer and researcher focusing on monetary policy, international finance and financial stability. He published articles in many home and foreign refereed academic and research journals. During his career he cooperated with consulting and business companies in the field of derivatives valuation, hedge accounting, investment strategies and dynamics of interest rates.

\section{REFERENCES}

1. Bartolini, L., Bertola, G., and A. Prati. "Banks' Reserve Management, Transactions Costs, and the Timing of Federal Reserve Intervention." Journal of Banking and Finance 25, no. 7, 2001: 1287-1318.

2. Bartolini, L., Bertola, G., and A. Prati. "Day-To-Day Monetary Policy and the Volatility of the Federal Funds Interest Rate.” Journal of Money, Credit, and Banking 34, no. 2, 2002: 137-159.

3. Bindseil, U. The Operational Target of Monetary Policy and the Rise and Fall of Reserve Position Doctrine. Frankfurt am Main: ECB, 2004 (Working Paper No. 372).

4. Bindseil, U., Camba-Mendez, G., Hirsch, A., and B. Weller. Excess Reserves and the Implementation of Monetary Policy of the ECB. Frankfurt am Main: ECB, 2004 (Working Paper No. 361).

5. Bindseil, U., and F. Seitz. The Supply and Demand for Eurosystem Deposits: The First 18 Months. Frankfurt am Main: ECB, 2001 (Working Paper No. 44).

6. Demiralp, S., and O. Jordá. "The Announcement Effect: Evidence from Open Market Desk Data." Federal Reserve Bank of New York Economic Policy Review 8, no. 1: 1-20.

7. ECB. Bidding Behaviour of Counterparties in the Eurosystem's Regular Open Market Operations. European Central Bank Monthly Bulletin, no. 10, 2001: 51-63.

8. ECB. The Liquidity Management of the ECB. European Central Bank Monthly Bulletin, no. 5, 2002: 4153. 
9. $\quad$ ECB. The Monetary Policy of the ECB 2008. Frankfurt am Main: ECB, 2008.

10. FRBNY. Domestic Open Market Operations during 2007. New York: Federal Reserve Bank of New York, 2008.

11. Gaspar, V., Quirós, G. P., and H. R. Mendizábal. Interest Rate Determination in the Interbank Market. Frankfurt am Main: ECB, 2004 (Working Paper No. 351).

12. Hamilton, J. D. "The Daily Market for Federal Funds.” Journal of Political Economy 104, no. 2, 1996: 2656.

13. Prati, A., Bartolini, L., and G. Bertola. The Overnight Interbank Market: Evidence from the G-7 and the Eurozone. CEPR, 2002 (CEPR Working Paper No. 3090).

14. Taylor, J. B. "Expectations, Open Market Operations, and Changes in the Federal Funds Rate." Federal Reserve Bank of St. Louis Review 83, no. 4, 2002: 33-47.

15. Whitesell, W. Monetary Policy Implemenation without Averaging or Rate Corridors. Washington: Federal Reserve Board, 2006 [Finance and Economics Discussion Series 2006-22].

16. Whitesell, W., Tunnels and Reserves in Monetary Policy Implementation. Washington: Federal Reserve Board, 2003 (Finance and Economics Discussion Series 2003-28).

17. Woodford, M. Monetary Policy in the Information Economy. Cambridge: NBER, 2001 (NBER Working Papers No. 8674). 
NOTES 